\title{
Paid Work \& Decision Making Power of Married Women Cross Sectional Survey of Muzaffarabad Azad State of Jammu \& Kashmir
}

\author{
Sheeba Arooj ${ }^{1 *}$, Wafa Hussain ${ }^{2}$, Amber Arooj $^{3}$, Asif Iqbal ${ }^{2}$, Saqib Hameed ${ }^{2}$, Atif Abbasi ${ }^{4}$ \\ ${ }^{1}$ Institute of Social \& Cultural Studies, University of Punjab, Lahore, Pakistan \\ ${ }^{2}$ Department of Sociology \& Rural Development, University of Azad Jammu \& Kashmir, \\ Muzaffarabad, Pakistan \\ ${ }^{3}$ Extension Services Management Academy, Ghari Dupatta, Muzaffarabad, Pakistan \\ ${ }^{4}$ Department of Statistics, University of Azad Jammu \& Kashmir, Muzaffarabad, Pakistan \\ Email: "sarooj45@yahoo.com \\ Received March 23 $3^{\text {rd }}, 2013$; revised April 26 ${ }^{\text {th }}, 2013$; accepted May $4^{\text {th }}, 2013$
}

Copyright (C 2013 Sheeba Arooj et al. This is an open access article distributed under the Creative Commons Attribution License, which permits unrestricted use, distribution, and reproduction in any medium, provided the original work is properly cited.

\begin{abstract}
Background: Current research focuses primarily on women's autonomy in decision making while little attention is paid to their freedom of expression. Socioeconomic \& socio-demographic factors affect women's autonomy in decision making. In the developing countries, particularly in Pakistan, although women are making significant financial contributions but they are still under collective decisions of husband and other family members while sometimes they are blindly relying on husband's decision. Objective of study was to find out association of women's autonomy in decision making \& socioeconomic factors. Method: Cross sectional survey was conducted in Muzaffarabad Azad Kashmir on married working women $(\mathrm{N}=500)$. The data consist of women's three decisions: birth control decision, financial decision and freedom of expression. A number of socio-demographic variables were used in chi-square analysis to examine the association of these variables with the said decisions. Results: Age, residence, education, professional differences, job nature, monthly income of married women are positively associated with autonomy in decision making. 59\% women of above 30 years age exercise independence in birth control decisions ( $p$ value 0.02 ). Urban women (96\%) are more likely to be autonomous in birth control decision than women from rural areas ( $p$ value 0.00 ). Educational attainment effects women autonomy as professionally qualified women (87.2\%) are more independent in birth control decisions, independent in spending income (86.5\%), having freedom of expression (55.4\%). Furthermore women living in nuclear families exercise more independence in birth control decisions (77.2), income spending decisions (76) and enjoy more freedom of expression (56.2). Women working in government sector have independence in birth control (71), financial decisions (70.4), and freedom of expression (52.4\%) with $p$ value 0.00 . Women earning salary of above 20,000 enjoy autonomy in birth control decisions (87.5\%), financial decisions (87.2\%), freedom of expression (57.4) with $p$ value 0.00 .
\end{abstract}

Keywords: Women; Decision; Birth Control; Financial Decision; Freedom of Expression; Chi-Square

\section{Introduction}

Socio-demographic factors affect women's independence in making decisions regarding health, household, family planning etc are poorly studied in Muzaffarabad AJK. Women's economic dependency has long been understood to be a major factor in structuring inequalities between men and women. Control over financial resources is often considered a central dimension when measuring women's household position.

Women's role has been a priority factor not only for sustainable development, but also in reproductive health. Autonomy is the ability to gain information and make decisions about concerns of one's own (Dyson, Moore et al., 1983). Autonomy facilitates easy access to material resources such as food, land,

*Corresponding author. income and other forms of wealth and social resources such as knowledge, power, prestige within the family and community (Dixon, 1978).

In Muzaffarabad out of 0.632 million population 0.305 million are females (projected population 2010 census 1998).

Women of working class families exert more influence in decisions of family than women of middle class. And no matter they are employed or not, wives in working-class families have more say in family decision-making than wives in middle-class families. It is also found that there is a positive association between the number of children and the influence of the husband in decision-making (Heer \& David, 1958).

\section{Situation in Pakistan}

In Pakistan women who met their fiance prior marriage were 
one quarter and those who put into decision of choosing life partner were $11.5 \%$. More than $50 \%$ women discussed with their partner regarding use of contraceptives and the percentage of women agreed on number of children was $44.2 \%$. Women who have freedom in selection of spouse are more likely to make decisions regarding number of children. Adoptions of contraceptives were more likely to be associated more with older age and higher education at marriage (Saima \& Stephenson, 2011).

In Pakistan the region more than the religion plays an important role in defining the autonomy of women. Autonomy of women in decision making is positively associated with employment, number of living children and their ages. Women of rural areas have relatively less autonomy in decision making. Autonomy in decision making is related with education of women. Interestingly women who are rich have less independence to make decisions about their health care. Women's condition was also unsatisfactory with respect to access and control over economic resources. Women who could speak in household spending were $59 \%$ whereas $70.4 \%$ women were those who could spend money in their homes by themselves, which means the majority of the women. But in case of buying valuable things, participation of women were limited to $16 \%$ i.e. those who could buy small jewellery, and women who could buy gifts by their own were $23.7 \%$. Women who could own and have control on their valuable things were $61.1 \%$ and those who could speak in their dowry related decisions were $33.6 \%$. 28.9\% of women could speak in husband's home in different matters. Women have little control over her savings by themselves (Jejeebhoy \& Shireen, 2001).

Increased autonomy of women in different aspects of life is related with paid work. In many village, areas mobility of women is restricted and women practice "purdah". In the rural areas, paid work is considered undesirable because it involves working outside the home and therefore only the poorest women engage in work as farm labourers, and agricultural labourers are amongst the lowest paid group in the rural sector. Poverty therefore is a major determinant that drives women into low-wage work (Kazi \& Shahnaz, 1999). Women had to do household tasks along with paid work because their husbands did not help them (Shaheed \& Farida, 1981). Study conducted in Multan revealed that $42.9 \%$ working women were those who had to take permission from family for going outside. $36 \%$ argued that their brothers got more privilege as compared to them from their parents (Ali \& Ishaque, 2010).

Addressing gender inequality issues Pakistan is far from ideal however there are significant efforts made by social protection projects as it provided numerous benefits to women in term of cash empowerment which has shown to improve decision making power of those women. They are more likely to use reproductive health services, moreover household investments shift from transportation and food to medical care, education, fuel, lighting, footwear and clothing.

Employment and education have always empowered women and brought a positive impact on decision making, including reducing the inequalities among men and women. One effective method to do so is to incorporate the notion of empowerment in school curricula. Attention should also be given to those women who do not attend school, through non-formal education. A curriculum for such programmes should be developed with a clear policy framework to reduce differences in education and employment between men and women (Mumtaz \& Salway, 2007). Employment of women is positively associated with delayed marriage and child birth (Jensen, 2012). Women of urban areas are more involved in working and they exercise control over their earnings and in discussion of family planning with their husbands than women of rural areas. More adoption of family planning is associated with educational level of women (Furuta, 2006). In structuring inequality between men \& women, economic dependency plays an important role. For measuring household position, the important dimension is women's control over financial resources (Standing, 1991).

Married Women having paid work \& education are more likely to participate in decision making (Roth, 2001). Independence of women in decision making is positively associated with employment, education, number of living children and age. Rural women with no education could not exercise autonomy in decision making (Ahmmed \& Chakraborty, 2012). Women with completed higher education are considered for consent of marriage (93.3\%), enjoy higher purchasing power (46.7\%), autonomous in decisions regarding politics (86.7\%) whereas illiterate women have no say in marriage related decision, having no purchasing power $(0.0 \%)$ and political decision making (77.8\%) (Sanjoy, 2012). Contraceptive use is significantly associated with decision autonomy than autonomy of movement (Saleem \& Bobak, 2005).

\section{Methodology}

A cross sectional descriptive study was conducted in district Muzaffarabad. A sample of 500 married working women was taken as per judgement of researcher because number of working women was limited (purposive sampling).

\section{Data Collection}

A close ended structured questionnaire was used to collect data of participants regarding decision making power with regard to birth control, independence in income spending and freedom of expression. The level of the questionnaire was that of layman understanding.

\section{Inclusion \& Exclusion Criteria}

Present study excluded unmarried and non-working women as primary interest of researcher was to find out changing role of married working women.

\section{Analysis}

Data were entered and analysed using SPSS software version 20. Both descriptive (percentage) and inferential (chi-square) statistics were used for data analysis. Results on the variables were presented with cross tabulation.

\section{Measures}

Independent variables which were chosen to represent decision making in above said areas were age, residence, education (primary and secondary were recorded into secondary), job title, job nature, family type, monthly income and expenses afforded by women. Bivariate analysis was performed to check out the association between variables.

\section{Results}

Table 1 describes that Working married women between age 
Table 1.

Response of respondents about different variable.

\begin{tabular}{|c|c|c|c|}
\hline Characteristics & Variable & Frequency & $\%$ \\
\hline \multirow{3}{*}{ Age } & $20-25$ years & 86 & 17.2 \\
\hline & $26-30$ & 165 & 33.0 \\
\hline & Above 30 & 249 & 49.8 \\
\hline \multirow{2}{*}{ Residence } & Urban & 250 & 50 \\
\hline & Rural & 250 & 50 \\
\hline \multirow{3}{*}{ Education } & Secondary & 47 & 9.4 \\
\hline & Higher secondary & 157 & 31.4 \\
\hline & Professional & 296 & 59.2 \\
\hline \multirow{4}{*}{ Job title } & Banking & 56 & 11.2 \\
\hline & Teaching & 241 & 48.2 \\
\hline & Medical & 85 & 17.0 \\
\hline & Any other & 118 & 23.6 \\
\hline \multirow{4}{*}{ Nature of job } & Government & 355 & 71.0 \\
\hline & Private & 120 & 24.0 \\
\hline & Business & 18 & 3.6 \\
\hline & Any other & 7 & 1.4 \\
\hline \multirow{4}{*}{ Family type } & Nuclear & 333 & 66.6 \\
\hline & Joint & 154 & 30.8 \\
\hline & Extended & 9 & 1.8 \\
\hline & Any other & 4 & 0.8 \\
\hline \multirow{4}{*}{ Family caste } & Syed & 55 & 11.0 \\
\hline & Mughal & 61 & 12.2 \\
\hline & Chaudary & 53 & 10.6 \\
\hline & Any other & 331 & 66.2 \\
\hline \multirow{5}{*}{$\begin{array}{l}\text { Average monthly } \\
\text { income }\end{array}$} & Less than 5000 & 18 & 3.6 \\
\hline & $5000-10,000$ & 56 & 11.2 \\
\hline & $11,000-15,000$ & 55 & 11.0 \\
\hline & $16,000-20,000$ & 75 & 15.0 \\
\hline & Above 20,000 & 296 & 59.2 \\
\hline \multirow{2}{*}{$\begin{array}{l}\text { Independence of } \\
\text { field selection }\end{array}$} & Yes & 154 & 30.8 \\
\hline & No & 346 & 69.2 \\
\hline \multirow{2}{*}{$\begin{array}{l}\text { Freedom of } \\
\text { expression }\end{array}$} & Yes & 241 & 48.2 \\
\hline & No & 259 & 51.8 \\
\hline \multirow{2}{*}{$\begin{array}{l}\text { Your suggestion } \\
\text { beign valued by } \\
\text { husband }\end{array}$} & Yes & 257 & 51.4 \\
\hline & No & 243 & 48.6 \\
\hline \multirow{2}{*}{$\begin{array}{l}\text { Allowed to make } \\
\text { decision of birth } \\
\text { control }\end{array}$} & Yes & 266 & 53.2 \\
\hline & No & 234 & 46.8 \\
\hline \multirow{4}{*}{$\begin{array}{l}\text { Selection of } \\
\text { number of children is } \\
\text { made by }\end{array}$} & Husband & 179 & 35.8 \\
\hline & In-laws (mother, father) & 32 & 6.4 \\
\hline & Your own & 1 & 0.2 \\
\hline & You and your husband & 287 & 57.4 \\
\hline \multirow{3}{*}{$\begin{array}{c}\text { Expenses afforded by } \\
\text { women }\end{array}$} & Complete & 132 & 26.4 \\
\hline & Partially & 239 & 47.8 \\
\hline & Free will & 129 & 25.8 \\
\hline \multirow{2}{*}{$\begin{array}{l}\text { Independent in } \\
\text { managing } \\
\text { financial decisions }\end{array}$} & Yes & 245 & 49.0 \\
\hline & No & 255 & 51.0 \\
\hline \multirow{2}{*}{$\begin{array}{l}\text { Independence in } \\
\text { spending your } \\
\text { income }\end{array}$} & Yes & 263 & 52.6 \\
\hline & No & 236 & 47.2 \\
\hline \multirow{2}{*}{$\begin{array}{l}\text { Working women has } \\
\text { financial } \\
\text { control in family }\end{array}$} & Yes & 398 & 79.6 \\
\hline & No & 101 & 20.2 \\
\hline \multirow{2}{*}{$\begin{array}{l}\text { Independent in } \\
\text { decision regarding } \\
\text { investment }\end{array}$} & Yes & 348 & 69.6 \\
\hline & No & 152 & 30.4 \\
\hline
\end{tabular}

group of above 30 years were $49.8 \%$. Working women of urban area were $50 \%$, and $50 \%$ were of rural areas. As far as their educational attainment is concerned $59.2 \%$, women were having professional qualification, $48.2 \%$ women were teachers, $71 \%$ were working in government sector. Sampled women belonging to nuclear family were $66.6 \%$. $59.2 \%$ women were earning above 20,000 monthly incomes. $69.2 \%$ women were not independent to choose any job field of their choice. 51.8\% women were having no freedom of expression, suggestion being valued and acknowledged by husband were 51.4\%. 53.2\% were allowed to make decision regarding birth control as far as decision regarding selection of number of children is concerned, $57.4 \%$ decisions were made by collaboration of both husband and wife. $47.8 \%$ were having partial responsibility to afford expenses at home. 51\% were no independent in financial decisions. Women who were independent in spending income were $52.6 \%$. $79.6 \%$ women were of view that working women have financial control in family. 69.6\% women were having independence in decisions regarding investment of income.

Table 2 shows that that $59.4 \%$ women (above 30 years) were having independence and 53.3\% (26 - 30) were having no autonomy in birth control decisions. Age of married working women had strong positive association with autonomy in birth control decisions ( $p$-value 0.02). As far as residence is concerned as depicted in Figure 1, 96.8\% urban women were having independence in decisions \& 90.4\% rural women were not autonomous in decision regarding birth control. Residential patterns are significantly associated with autonomy in birth control decisions ( $p$ 0.00). 95.7\% (secondary level education) women were not independent, 96.2\% (higher secondary) were not. Whereas professionally qualified women were having autonomy in this regard was $87.2 \%$, so the educational attainment of respondent was significantly associated with birth control decisions ( $p$ 0.00). Women working in medical sector were independent (62.4\%), whereas $62.5 \%$ banker women were not independent in birth control decisions. Professional differences are associated with independence in reproductive health decisions ( $p$ 0.01). Women working in government sector were autonomous $71 \%$ whereas in private sector $92.5 \%$ were having no autonomy. Nature of women's job is significantly associated with independence in birth control decisions ( $p$ 0.00). Women of nuclear family were independent (77.2\%) whereas in extended families, $100 \%$ were having no type of family which is significantly associated with birth control decisions $(p 0.00)$. Women getting salary above 20,000 were $87.5 \%$ independent whereas women getting lower salaries enjoy less independence $p 0.00$.

Table 3 shows that older age women were more independent in income spending by their own (58.8\%) than rest of age categories women of urban area who were having independence (95.6\%) whereas $4 \%$ having not. In rural areas $9.6 \%$ women were independent whereas $90.4 \%$ women were not independent in this regard. Residential pattern is significantly associated with independence in income spending $(p 0.00)$. As far as educational attainment is concerned $90.4 \%$ women of secondary level education were not independent whereas of higher secondary level $96.8 \%$ were not, $86.5 \%$ professionally qualified women were having independence with $p$ value 0.00 .

Medical professionals were comparatively more independent (60\%) and women of banking sector were less likely to make financial decisions (58.9\%) in family. Government sector working women were having independence (70\%) and those working in business sector were having no independence (88.9\%) 
Table 2.

Reproductive health decisions against socioeconomic factors.

\begin{tabular}{|c|c|c|c|c|c|}
\hline \multirow[b]{2}{*}{ Characteristics } & & \multicolumn{2}{|c|}{ Birth control } & \multirow[b]{2}{*}{ Chi-square value } & \multirow[b]{2}{*}{$p$ value } \\
\hline & & $\begin{array}{c}\text { Yes } \\
\text { F (\%) }\end{array}$ & $\begin{array}{c}\text { No } \\
\mathrm{F}(\%)\end{array}$ & & \\
\hline \multirow{3}{*}{ Age } & 20 - 25 years & $41(47.7)$ & $45(52.3)$ & \multirow{3}{*}{7.77} & \multirow{3}{*}{0.02} \\
\hline & $26-30$ & $77(46.7)$ & $88(53.3)$ & & \\
\hline & Above 30 & 148 (59.4) & $101(40.6)$ & & \\
\hline \multirow{2}{*}{ Residence } & Urban & 242 (96.8) & $8(3.2)$ & \multirow{2}{*}{381.75} & \multirow{2}{*}{0.00} \\
\hline & Rural & $24(9.6)$ & $226(90.4)$ & & \\
\hline \multirow{3}{*}{ Education } & Secondary & $2(4.3)$ & 45 (95.7) & \multirow{3}{*}{336.10} & \multirow{3}{*}{0.00} \\
\hline & Higher secondary & $6(3.8)$ & $151(96.2)$ & & \\
\hline & Professional & $258(87.2)$ & $38(12.8)$ & & \\
\hline \multirow{4}{*}{ Job title } & Banking & $21(37.5)$ & $35(62.5)$ & \multirow{4}{*}{10.82} & \multirow{4}{*}{0.01} \\
\hline & Teaching & $122(50.6)$ & 119 (49.4) & & \\
\hline & Medical & $53(62.4)$ & 32 (37.6) & & \\
\hline & Any other & $70(59.3)$ & $48(40.7)$ & & \\
\hline \multirow{4}{*}{ Nature of job } & Government & $252(71)$ & 103 (29) & \multirow{4}{*}{157.11} & \multirow{4}{*}{0.00} \\
\hline & Private & $9(7.5)$ & $111(92.5)$ & & \\
\hline & Business & $3(16.7)$ & $15(83.3)$ & & \\
\hline & Any other & $2(28.6)$ & $5(71.4)$ & & \\
\hline \multirow{5}{*}{ Family type } & Nuclear & $257(77.2)$ & $76(22.8)$ & \multirow{4}{*}{230.38} & \multirow{4}{*}{0.00} \\
\hline & Joint & $9(5.8)$ & $145(94.2)$ & & \\
\hline & Extended & $0(0)$ & $9(100)$ & & \\
\hline & Any other & $0(0)$ & $4(100)$ & & \\
\hline & Less than 5000 & $0(0)$ & $18(100)$ & \multirow{5}{*}{343.01} & \multirow{5}{*}{0.00} \\
\hline \multirow{3}{*}{ Average monthly income } & $5000-10,000$ & $2(3.6)$ & $54(96.4)$ & & \\
\hline & $11,000-15,000$ & $3(5.5)$ & $52(94.5)$ & & \\
\hline & $16,000-20,000$ & $2(2.7)$ & $73(97.3)$ & & \\
\hline \multirow{4}{*}{$\begin{array}{l}\text { Expenses afforded by } \\
\text { women }\end{array}$} & Above 20,000 & 259 (87.5) & 37 (12.5) & & \\
\hline & Complete & 76 (57.6) & $56(42.4)$ & \multirow{3}{*}{5.61} & \multirow{3}{*}{0.06} \\
\hline & Partial & $114(47.7)$ & $125(52.3)$ & & \\
\hline & Free will & 76 (58.9) & 53 (41.1) & & \\
\hline
\end{tabular}

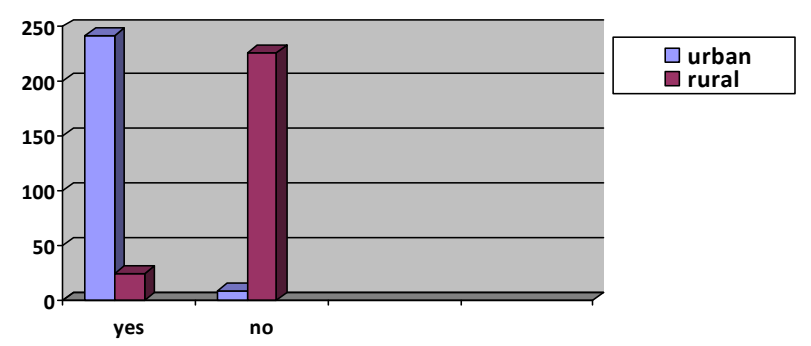

Figure 1.

Birth control decisions \& residece $p=0.000$.

with $p$-value 0.00 . Women of nuclear family exercise independence (76\%) whereas in joint family women have no independence (94\%) in extended families (100\%). Family type is significantly associated with women's independence in financial decisions. Women earning more than 20,000 were exercising independence (87.2\%) whereas women earning less than 5000 were having no independence (100\%). Monthly earning of women is associated with their independence in this regard with $p$ value 0.00 . Women who are supposed to afford financial burden of family on their free will exercise independence $61.2 \%$ with $p$ value 0.01 .

Table 4 shows that women of urban areas were having freedom of expression (58.8\%) whereas in rural areas $62.4 \%$ women were having no freedom and residence is associated with freedom of expression with $p$ value 0.00 . Professionally qualified women were having independence in expressing their ideas $(55.4 \%)$ whereas $66 \%$ women were not independent in this regard significantly associated with $p$ value 0.00 . Women working in private sector have no independence in this regard $(65.8 \%)$ significantly associated with $p$ value 0.00 . Women of nuclear family enjoy freedom of expression (56.2\%) with $p$ value 0.00 . Women earning more than 20,000 exercise freedom of expression (57.4\%) and those with earning less than 5000 (77.8\%) were having no independence. Monthly income of women is significantly associated with freedom of expression with $p$ value 0.00 . Women who are supposed to afford complete financial burden of family exercise independence in this regard $57.6 \%$ whereas $58.1 \%$ women were having no independence who were supposed to afford financial burden on their free will. 
Table 3.

Financial decision against socioeconomic factors.

\begin{tabular}{|c|c|c|c|c|c|}
\hline \multirow{3}{*}{ Characteristics } & & \multicolumn{2}{|c|}{ Independence in income spending } & \multirow{3}{*}{ Chi-square value } & \multirow{3}{*}{$p$ value } \\
\hline & & Yes & No & & \\
\hline & & F (\%) & F (\%) & & \\
\hline \multirow{3}{*}{ Age } & 20 - 25 years & $42(48.8)$ & $44(51.2)$ & \multirow{3}{*}{8.26} & \multirow{3}{*}{0.08} \\
\hline & $26-30$ & $76(46.1)$ & 88 (53.3) & & \\
\hline & Above 30 & $145(58.2)$ & $104(41.8)$ & & \\
\hline \multirow{2}{*}{ Residence } & Urban & 239 (95.6) & $10(4)$ & \multirow{2}{*}{374.45} & \multirow{2}{*}{0.00} \\
\hline & Rural & $24(9.6)$ & $226(90.4)$ & & \\
\hline \multirow{3}{*}{ Education } & Secondary & $2(4.3)$ & $45(95.7)$ & \multirow{3}{*}{337.02} & \multirow{3}{*}{0.00} \\
\hline & Higher secondary & $5(3.2)$ & $152(96.8)$ & & \\
\hline & Professional & $256(86.5)$ & 39 (13.2) & & \\
\hline \multirow{4}{*}{ Job title } & Banking & $23(41.1)$ & 33 (58.9) & \multirow{4}{*}{9.49} & \multirow{4}{*}{0.14} \\
\hline & Teaching & $122(50.6)$ & $119(49.4)$ & & \\
\hline & Medical & $51(60)$ & $34(40)$ & & \\
\hline & Any other & $67(56.8)$ & $50(42.4)$ & & \\
\hline \multirow{4}{*}{ Nature of job } & Government & $250(70.4)$ & $104(29.3)$ & \multirow{4}{*}{158.68} & \multirow{4}{*}{0.00} \\
\hline & Private & $9(7.5)$ & $111(52.5)$ & & \\
\hline & Business & $2(11.1)$ & 16 (88.9) & & \\
\hline & Any other & 2 (28.6) & $5(71.4)$ & & \\
\hline \multirow{4}{*}{ Family type } & Nuclear & $253(76)$ & 79 (23.7) & \multirow{4}{*}{221.20} & \multirow{4}{*}{0.00} \\
\hline & Joint & $9(5.8)$ & $145(94.2)$ & & \\
\hline & Extended & $0(0)$ & $9(100)$ & & \\
\hline & Any other & $1(25)$ & $3(75)$ & & \\
\hline \multirow{4}{*}{ Average monthly income } & Less than 5000 & $0(0)$ & $18(100)$ & \multirow{5}{*}{350.65} & \multirow{5}{*}{0.00} \\
\hline & $5000-10,000$ & $1(1.8)$ & $55(98.2)$ & & \\
\hline & $11,000-15,000$ & $1(1.8)$ & $54(98.2)$ & & \\
\hline & $16,000-20,000$ & $3(4)$ & $72(96)$ & & \\
\hline \multirow{4}{*}{$\begin{array}{l}\text { Expenses afforded by } \\
\text { women }\end{array}$} & Above 20,000 & $258(87.2)$ & 37 (12.5) & & \\
\hline & Complete & $75(56.8)$ & $56(42.4)$ & \multirow{3}{*}{12.49} & \multirow{3}{*}{0.01} \\
\hline & Partial & $109(45.6)$ & $130(54.4)$ & & \\
\hline & Free will & $79(61.2)$ & $50(38.8)$ & & \\
\hline
\end{tabular}

So level of expenses afforded by women is associated with freedom of expression with $p$ value 0.03 .

\section{Discussion}

Purpose of study was to explore link between socioeconomic factors \& autonomy in decision making. Reproductive health decisions are increased with advancement of age of working women whereas women of younger age group are less likely to participate in birth control decisions. Regional differences effect women's autonomy in reproductive health decisions, income spending decisions and freedom of expression as elaborated younger urban women enjoy greater autonomy in above said decisions whereas rural women are still under collective decisions of husbands and other family members. Urban areas are characterized by better use of facilities (health services \& education). Some advantaged urban women have exceed their rural counterparts because of higher levels of knowledge, access to services and health promotion programs that use urbanfocused mass media, thus leaving out their rural counterparts who may be largely influenced by traditional practices. Results of this study confirm this advantage with significant statistical significance.

As far as educational attainment of married working women is concerned, women having general education degrees (secondary \& higher secondary) are less likely to be autonomous in expressing their ideas freely. First possible explanation of finding is that women with secondary $(9.4 \%)$ \& higher secondary education (31.4\%) are low compared to professional qualification. In deciding number of children, how and when to spend income, in contrast professionally qualified women exercise more independence in all said decision because of having professional skills, social exposure etc. Professional differences are associated with reproductive health decisions as it affects women's autonomy of decisions of birth control, women working in medical profession enjoys more independence in this regard. Women of nuclear family (husband, wife \& unmarried children) are more empowered to decide than those of joint and extended families as women of joint and extended families are still under decisions of husbands, in-laws and others. 
Table 4.

Freedom of expression against socio-demographic factors.

\begin{tabular}{|c|c|c|c|c|c|}
\hline \multirow{3}{*}{ Characteristics } & & \multicolumn{2}{|c|}{ Freedom of expression } & \multirow{3}{*}{ Chi-square value } & \multirow{3}{*}{$p$ value } \\
\hline & & \multirow{2}{*}{$\begin{array}{c}\text { Yes } \\
\mathrm{F}(\%)\end{array}$} & \multirow{2}{*}{$\begin{array}{c}\text { No } \\
\text { F (\%) }\end{array}$} & & \\
\hline & & & & & \\
\hline \multirow{2}{*}{ Residence } & Urban & $147(58.8)$ & $103(41.2)$ & \multirow{2}{*}{22.50} & \multirow{2}{*}{0.00} \\
\hline & Rural & $94(37.6)$ & $156(62.4)$ & & \\
\hline \multirow{3}{*}{ Education } & Secondary & $16(34)$ & $31(66)$ & \multirow{3}{*}{15.42} & \multirow{3}{*}{0.00} \\
\hline & Higher secondary & 61 (38.9) & 96 (61.1) & & \\
\hline & Professional & $164(55.4)$ & $132(44.6)$ & & \\
\hline \multirow{4}{*}{ Job title } & Banking & $21(37.5)$ & $35(62.5)$ & \multirow{4}{*}{4.28} & \multirow{4}{*}{0.23} \\
\hline & Teaching & $116(48.1)$ & 125 (51.9) & & \\
\hline & Medical & $47(55.3)$ & $38(44.7)$ & & \\
\hline & Any other & $57(48.3)$ & $61(51.7)$ & & \\
\hline \multirow{4}{*}{ Job nature } & Government & $186(52.4)$ & 169 (47.6) & \multirow{4}{*}{12.58} & \multirow{4}{*}{0.00} \\
\hline & Private & $41(34.2)$ & $79(65.8)$ & & \\
\hline & Business & $10(55.6)$ & $8(44.4)$ & & \\
\hline & Any other & $4(57.1)$ & $3(42.9)$ & & \\
\hline \multirow{5}{*}{ Family type } & Nuclear & $187(56.2)$ & $146(43.8)$ & \multirow{4}{*}{25.36} & \multirow{4}{*}{0.00} \\
\hline & Joint & $50(32.5)$ & $104(67.5)$ & & \\
\hline & Extended & $3(33.3)$ & $6(66.7)$ & & \\
\hline & Any other & $1(25)$ & $3(75)$ & & \\
\hline & Less than 5000 & $4(22.2)$ & $14(77.8)$ & \multirow{5}{*}{26.12} & \multirow{5}{*}{0.00} \\
\hline \multirow{3}{*}{ Average monthly income } & $5000-10,000$ & $21(37.5)$ & $35(62.5)$ & & \\
\hline & $11,000-15,000$ & $20(36.4)$ & 35 (63.6) & & \\
\hline & $16,000-20,000$ & $26(34.7)$ & 49 (65.3) & & \\
\hline \multirow{4}{*}{$\begin{array}{c}\text { Expenses afforded by women at } \\
\text { home }\end{array}$} & Above 20,000 & $170(57.4)$ & $126(42.6)$ & & \\
\hline & Complete & 76 (57.6) & $56(42.4)$ & \multirow{3}{*}{7.01} & \multirow{3}{*}{0.03} \\
\hline & Partial & $111(46.4)$ & $128(53.6)$ & & \\
\hline & Free will & 54 (41.9) & 75 (58.1) & & \\
\hline
\end{tabular}

Monthly earning level of women alters women independence in decision making as cited in Tables 2-4 women getting higher salaries exercise greater control. Higher salaried women worker enjoy more independence. Present study confirms this with statistical significance. Women who are responsible to support complete financial burden of family are more likely to be autonomous in managing financial decisions independently as well as expressing their ideas with their family members freely whereas those who support family partially or on free will exercise little independence in decision making.

\section{Conclusion}

Present study investigated the role of women in family \& society which is changing but still women of rural area and those having low salaries are vulnerable to be subordinate to husband \& other family members, and structure of family is strong indicator of deciding women's position in household and in society. Along with these factors women who support financial burden of family are more likely to be free to express their ideas. To the best of our knowledge, this is first time study on particular issue in Muzaffarabad Azad Kashmir.

\section{Recommendation}

As investigated from the study, it is dire need of time to fo- cus attention toward empowerment of women of rural area as rural women is victimized in all of above said decisions. Along with educating women at individual level, this is equally important to educate husband \& other members of family regarding role of women because women living in joint \& extended families still rely on husband and other family members about decisions on reproductive health and others. In secondary and higher level schooling, there should be certain training sessions for female students regarding their role \& autonomy in decision making.

\section{REFERENCES}

Ahmmed, M., \& Chakraborty, N. (2012). Women's status and early childhood mortality in bangladesh.

http://maternalhealthtaskforce.org/component/docman/doc_view/133 3-women-s-status-and-earlychildhood-mortality-in-bangladesh?Itemi $\mathrm{d}=220$

Ali, W., Ishaque, M. F., Saima, A., \& Yasin, G. (2010). Cultural barriers in women empowerment: A sociological analysis of Multan, Pakistan. European Journal of Social Sciences, 18, 147-155.

Dixon, R. B. (1978). Rural women at work: Strategies for development in South Asia. Baltimore: Johns Hopkins University Press.

Dyson, T., \& Moore, M. (1983). On kinship structure, female autonomy, and demographic behaviour in India. Population and Development Review, 9, 35-60. doi:10.2307/1972894

Furuta, M., \& Salway, S. (2006). Women's position within the house- 
hold as a determinant of maternal health care use in Nepal. International Family Planning Perspectives, 32, 17-27.

doi:10.1363/3201706

Heer, D. M. (1958). Dominance and working wife. Social Forces, 36, 34. doi:10.2307/2573973

Jejeebhoy, S. J., \& Sathar, Z. A. (2001). Women's autonomy in India and Pakistan: The influence of religion and region. Population and Development Review, 27, 687-712. doi:10.1111/j.1728-4457.2001.00687.x

Jensen, R. (2012). Do labor market opportunities affect young women's work and family decisions? Experimental evidence from India. The Quarterly Journal of Economics, 127, 753-792.

doi:10.1093/qje/qjs002

Kazi, \& Shahnaz (1999). Gender inequalities and development in Pakistan. In S. R. Khan (Ed.), 50 years of pakistan's economy: Traditional topics and contemporary concerns (pp. 376-414). Karachi: Oxford University Press.
Mumtaz, Z., \& Salway, S. M. (2007). Gender, pregnancy and the uptake of antenatal care services in Pakistan. Sociology of Health \& Illness, 29, 1-26. doi:10.1111/j.1467-9566.2007.00519.x

Roth, D. M., \& Mbzyo, M. I. (2001). Promoting safe motherhoodin the community. New Delhi: Reproductive Health.

Saima, H., Stephenson, R., \& Rubenson, B. (2011). Marriage decision making, spousal communication, and reproductive health among married youth in Pakistan. Global Health Action, 4, 5079.

Saleem, S., \& Bobak, M. (2005). Women's autonomy, education and contraception use in Pakistan: A national study. Reproductive Health, 2, 8. doi:10.1186/1742-4755-2-8

Sanjoy, K. C., Howlader, H., \& Nahar, N. (2012). Educational status of the married women and their participation at household decision making in rural Bangladesh. International Journal of Advancements in Research \& Technology, 1, 137-146.

Standing, H. (1991). Dependence and autonomy: Women's employment and the family in Calcutta. London and New York: Routledge. 